\title{
AFRICA AT THE WORLD TOURISM MARKET IN THE CONTEXT OF GLOBALIZATION*
}

\author{
Svitlana Iurchenko \\ PhD (Geography), Associate Professor \\ V.N. Karazin Kharkiv National University \\ Svobody sq., 4, Kharkiv, Ukraine, 61022 \\ e-mail: s.a.jurchenko@karazin \\ ORCID: https:/ / orcid.org/0000-0002-3709-4317 \\ Olena Iurchenko \\ Applicant \\ V.N. Karazin Kharkiv National University \\ Svobody sq., 4, Kharkiv, Ukraine, 61022 \\ e-mail: el-tour@hotmail.com \\ Anna Kondrova \\ PhD (Geography), Associate Professor \\ Moscow Pedagogical State University \\ e-mail: ae.kondrova@mpgu.su \\ ORCID: https://orcid.org/0000-0002-0535-678X
} M. Pirogovskaya Str. 1/1, Moscow, 119991, Russian Federation

\begin{abstract}
Tourism is a promising industry in the countries of African continent. It contributes to their economic growth and improves the living conditions of the population. The subject of the study is the tourism market in Africa. The purpose of the article is to show Africa's place at the world tourism market and to analyze trends of tourist activity in the region in the context of globalization. To achieve the goal, the following tasks were solved: to show factors affecting tourism activities in Africa, to analyze main parameters and trends of international tourism development in the region and its subregions in comparison with the world, to identify the impact of tourism on the economy of African countries. The following methods were used: comparative; historical - to identify trends in development of international tourism in Africa, statistical - to study the interdependence between quantitative indicators of tourism development in African countries; analysis and synthesis - to identify the relationship of processes occurring in tourism markets, systematic approach - to reveal the features of international tourism development in the context of globalization. The following results were obtained: periods of decline and growth of tourism activity in the continent as a whole, its macroregions and individual countries were identified; main areas of tourism and travel, main problems of tourism development were identified; connection between GDP and tourism development indicators in African countries was calculated; impact of COVID-19 on tourism business development in Africa was shown. Conclusions: international tourism is actively developing in Africa, making a significant contribution to GDP and employment. However, level of tourism development depends on a number of internal and external factors and lags behind the world average and other tourism subregions. There is a need to develop effective tourism policies in each country of the continent and its subregions.
\end{abstract}

Keywords: globalization, tourism, international tourism, world tourism market, Africa, African tourism subregions, tourist arrivals, tourism revenues.

Formulation of the problem. Africa accounts for $20 \%$ of the world's land mass, $16 \%$ of the population and only about 4\% of global GDP [18]. This, on the one hand, shows the inability of countries to engage the existing potential in continent development, and on the other hand, emphasizes the great opportunities, as well as the emergence of risks in the future.

The population (1.3 billion people) lives in 54 countries, varying in language, culture, religion, level of socio-economic development and stability. Africa is home to 19 of the Top 20 Fastest-Growing Populations in the world. According to forecasts, the population of this demographically young continent in 2020-2050 will increase to 2.5 billion people. (by 87\%) [22], and in 2025 the proportion of the population under 24 years old will be $60 \%$. By the middle of the 21st century, every third person in the world between the ages of 15 and 35 will live in Africa [15].

\footnotetext{
* Cite as: Iurchenko, S., Iurchenko, O., Kondrova, A. (2021). Africa at the World Tourism Market in the Context of Globalization, The Journal of V. N. Karazin Kharkiv National University. Series: International Relations. Economics. Country Studies. Tourism. 13, 216-227. https://doi.org/10.26565/2310-9513-2021-13-22
} 
But if Africa lags behind economically, it will continue to be a source of instability and extremism on a global scale. In turn, positive processes in the countries of African region can be a significant source of growth for the entire world. It is therefore important for Africa to decide on the development of priority sectors of the economy in order to take its rightful place in the global world.

In the global services trade market, tourism is a fast-growing industry. In 2019, Travel \& Tourism (T\&T) accounted for $6.8 \%$ of total exports, $28.3 \%$ of global services exports and $4.3 \%$ of total investment [17]. Since the end of the 20th century, it has developed rapidly in many regions and countries of the world, including African countries. This is due to the revival of the world economy, development of tourism infrastructure, spread of the Internet, mobile communications, availability of airline tickets, facilitation of visa regimes, etc. The active inclusion of this continent in a system of international tourist market requires a careful analysis of this phenomenon, because tourism and related industries are an important factor in solving its socio-economic problems and economic policy.

Analysis of recent research and publications. The works of I. Abramova, L. Fituni, A. Bgatov, R. Verdiev, N. Jackson, P. Ivans, D. Karakhanyan, I. Chris, P. Crompton, V. Melyantsev, F. Soyti, Y. Sologub, R. Fey, D. Honen and others are devoted to the study of tourism in Africa. L. Maksimova analyzes the problems of development of the hospitality industry in the countries of equatorial and southern Africa [6]. O. Konstantinova considers the development of tourism in Africa as an important direction of inclusive development of the continent, which can positively affect the development of the economies of this region and the world as a whole [4]. A. Aleksandrova singles out five main types of countries according to the level of development of international tourism. The fifth type includes developing countries on the periphery of the world tourist space with a low level of development of international tourism of enclave character. Here only the countries of East and Southern Africa (Botswana, Zimbabwe, Kenya, Namibia, Tanzania and Uganda) with unique natural potential and specialization on nature-oriented tourism are considered [1]. In our opinion, many other African countries can also be referred to this group. The study of trends, spatial organization, forms and directions of tourism development continues to be relevant because of the lack of development of tourism problems in the region.

The purpose of the article - to show Africa's place in the world tourism market and analyze trends in tourism activities in the region under conditions of globalization.

Research results. The development of international tourism is characterized by extreme unevenness in spatial and temporal relations. And, first of all, it is so due to different levels of social and economic development of countries and regions [12; 13]. Europe continues to occupy the leading position in the world tourist market, though its role is gradually weakening. This region accounts for more than half of the world's tourist arrivals and about $2 / 5$ of foreign exchange earnings (Table 1, Table 2).

Table 1

\section{International tourist arrivals by region}

\begin{tabular}{|l|c|c|c|c|c|c|c|}
\hline & \multicolumn{3}{|c|}{ Million } & Share, \% & \multicolumn{2}{c|}{ Change, \% } & Av. annual growth, \% \\
\cline { 2 - 8 } & 2010 & 2018 & 2019 & 2019 & $18 / 17$ & $19 / 18$ & $2010-2019$ \\
\hline World & 956 & 1,408 & 1,460 & 100 & 5.7 & 3.7 & 4.8 \\
\hline Advanced economies & 515 & 762 & 776 & 53.2 & 4.1 & 1.9 & 4.7 \\
\hline Emerging economies & 441 & 647 & 684 & 46.8 & 7.6 & 5.7 & 5.0 \\
\hline Europe & 491.2 & 716.3 & 744.0 & 51.0 & 5.9 & 3.9 & 4.7 \\
\hline Asia and the Pacific & 208.2 & 347.5 & 361.6 & 24.8 & 7.2 & 4.1 & 6.3 \\
\hline Americas & 150.3 & 215.9 & 219.3 & 15.0 & 2.4 & 1.5 & 4.3 \\
\hline Africa & 50.4 & 68.6 & 70.0 & 4.8 & 8.3 & 2.0 & 3.7 \\
\hline Middle East & 56.1 & 60.1 & 65.1 & 4.5 & 4.3 & 8.3 & 1.7 \\
\hline
\end{tabular}

Developed by the author on the basis of: [22]

International tourism receipts by region

\begin{tabular}{|l|l|l|l|l|l|l|}
\hline \multirow{2}{*}{} & \multicolumn{3}{|c|}{ USD billion } & \multicolumn{2}{l|}{ Share (\%) } & \multicolumn{2}{l|}{ Change (\%)* } \\
\cline { 2 - 7 } & 2010 & 2018 & 2019 & 2019 & $18 / 17$ & $19 / 18$ \\
\hline World & 980 & 1,460 & 1,481 & 100 & 5.0 & 2.5 \\
\hline Advanced economies & 644 & 948 & 946 & 63.8 & 4.1 & 1.6 \\
\hline Emerging economies & 336 & 512 & 536 & 36.2 & 6.5 & 4.3 \\
\hline Europe & 427.5 & 572.4 & 576.4 & 38.9 & 4.9 & 4.5 \\
\hline Asia and the Pacific & 254.3 & 436.5 & 443.2 & 29.9 & 8.8 & 1.1 \\
\hline Americas & 215.2 & 338.2 & 341.8 & 23.1 & 0.4 & -0.1 \\
\hline Africa & 30.4 & 38.9 & 38.4 & 2.6 & 2.6 & 0.8 \\
\hline Middle East & 52.2 & 74.5 & 81.5 & 5.5 & 6.0 & 8.5 \\
\hline
\end{tabular}

* In local currencies, constant prices (real terms)

Developed by the author on the basis of: [22] 
Developing countries are ahead of developed countries in terms of growth rates of international tourist arrivals and revenues from tourism. Africa's competitive advantages in tourism compared to other regions are shaped by:

- the proximity of Europe and Asia, major consumers of tourism services;

- uniqueness of historical and cultural attractions;

- diversity of exotic nature, including unique wildlife;

- ethnic traditions of numerous local peoples, distinguished by their unusual culture and history;

- diversity of non-standard routes;

- favorable climatic and natural features that allow vacationing on the beaches of many African coastal areas throughout the year.

Africa is still an underdeveloped, young but attractive, fast-growing and promising tourist region. Here, the number of tourist arrivals rose from 14.8 million in 1990 to 26.5 million in 2000 and to 49.4 million in 2010. [25]. Socio-economic, political and military instability, acts of terrorism and sometimes ecological disasters in some countries of the continent affect the tourism development. Periods of growth alternate with decline or stagnation. For example, in the 1980s, because of the spread of AIDS the number of tourist arrivals decreased. In order to attract tourists, African operators began to lower prices. As a result, the growth of revenues from tourism lagged behind the growth of arrivals. Since the mid-1990s, there has been a revival in the African tourism market.
At the beginning of the 21 st century, active tourism advertising, improvement of the quality of tourism products and services, liberalization and growth of air transport capacity, opening of cheap flights linking African countries with the main European destinations, as well as euro's strengthening had a general impact on the growth of tourism activities in Africa. But because of the frequent shocks of different nature, its tourism market has been unstable. This was negatively affected by: the global crisis of 2008-2009, the events of the "Arab Spring" in North Africa in 2010-2011; the outbreak of Ebola in West Africa in 2013-2014, terrorist attacks in Tunisia (2015), Nigeria (2011, 20152017), Somalia (2015), etc.

In 2019, Africa ranked 4th in tourist arrivals (4.8\% of global traffic) and 5 th in international tourism revenue (2.6\% of global revenue) among the 5 tourist macro-regions of the world. During the year, 70.0 million tourists crossed Africa's borders, which is $38.9 \%$ more than in 2010. In terms of growth in tourist arrivals for 2018-2019, Africa was second only to America and to the entire group of developed countries, but it was ahead of the Middle East in terms of average annual growth and significantly behind the entire group of developing countries. International tourism revenues fared even worse, but in terms of growth for 2018-2019, Africa was ahead of America, but has a minimal share of the global tourism market [28].

The total contribution of tourism to Africa's GDP in 2019 was US\$168.5 billion. This is below the global average of $10.3 \%$ (Table 3 ).

Table 3

T\&T Contribution to GDP and Jobs (2019)

\begin{tabular}{|l|l|l|l|l|l|l|}
\hline & $\begin{array}{l}\text { Contribution to } \\
\text { GDP (US\$) }\end{array}$ & $\begin{array}{l}\text { T\&T \% } \\
\text { GDP }\end{array}$ & $\begin{array}{l}\text { T\&T GDP } \\
\text { growth (\%) }\end{array}$ & $\begin{array}{l}\text { Jobs in T\&T } \\
2019 \text { (mn) }\end{array}$ & $\begin{array}{l}\text { T\&T \% of country } \\
\text { employment }\end{array}$ \\
\hline Africa & 168.5 billion & 7.1 & 2.2 & 24.6 & 6.8 \\
\hline $\begin{array}{l}\text { Sub- } \\
\text { Saharan } \\
\text { Africa }\end{array}$ & 107 billion & 6.5 & 2.1 & 19.7 & 6.4 \\
\hline North Africa & 61 billion & 8.5 & 2.4 & 4.9 & 9.3 \\
\hline World & 8.9 trillion & 10.3 & 3.5 & 330 & 10.4 \\
\hline
\end{tabular}

Developed by the author on the basis of: [24]

Africa's GDP of T\&T growth rate in 2019 was lower than the global economy $(2.5 \%)$ and global tourism (3.5\%). Health problems and armed conflicts are having an impact. The continent's largest contributors to GDP were Egypt (US\$29.5 bn), South Africa (US\$24.6 bn) and Nigeria (US\$18.1 bn). With an average growth of $2.2 \%$, the first place in Africa and the sixth in the world was taken by Tunisia, where the GDP of travel and tourism grew by $12.9 \%$, outpacing the overall economic growth of $1.3 \%$. The Tunisian government's measures to enhance security at tourist resorts and their ability to respond promptly to any threats had a positive impact on tourism in the country.
Rwanda also had a high GDP of T\&T growth rate in 2019 (10.9\%), where the government is focusing on sustainable tourism development. This has led to the creation and development of public, private and community partnerships, supporting local communities with tourism projects and contributing to the restoration and expansion of parks and nature conservation. Tourism in Kenya is actively developing (growth of $4.9 \%$ in 2019) as a result of the development of communication and prioritization by the government in this area, attracting private sector investments in projects related to the tourism sector [28]. 
In 2018, Ethiopia had the highest growth rate of the travel and tourism economy in the continent (48.6\% in 2018) as well as the highest economy growth rate in the world. This was possible mainly due to an increase in the flow and expenditures of international tourists due to the policy of easing the visa regime, development of infrastructure, transformation of Ethiopia into a regional transport hub [27].

Close ties between economic entities of different hierarchical levels increase the multiplier effect. As a result, they receive economic benefits at the national level, new jobs are created and well-being of the population at the local level is increased. However, the links between tourism and other sectors of the economy are poorly developed in most African countries. Therefore, part of the added value created in the tourism industry goes to foreign investors and airlines, international tour operators. And only a small part of it stays in the country itself and reaches the poorer segments of the population. Expanding ties would help create new jobs for women and youth, as well as for poor citizens.

The tourism sector, with its high labor intensity in terms of employment, has enormous potential on the continent. Creating new jobs, employing low-wage and unskilled workers is especially important for agricultural and remote areas, as well as for solving the unemployment problem. In 2018, the direct contribution of tourism to employment in Africa was about 10 million people [5], and the total contribution was 24.6 million (Table 3). Thus, one in every $14-15$ jobs on the continent is related to tourism. However, this is significantly lower than the world average (every 10th job) [28]. The creation of new jobs in the tourism-related industries will have a positive impact on reducing unemployment, poverty and bridging the gap between regions, rural areas.

The key problem for the development of the tourism industry is training of qualified personnel. For this purpose, schools of tourism and hospitality are created. At the same time, tourism employers often assume the cost of staff training.

A significant contribution to the development of tourism is made by women. In the G20 countries, they account for almost $50 \%$ of total employment in T\&T, which is $7 \%$ more than employment in the economy as a whole [29]. In Africa, women account for $60-70 \%$ of total employment in tourism industry, $30.5 \%$ of total employers (or $20.8 \%$ of women). About $50 \%$ of workers in the tourism industry are 25 years of age or younger. Of these, $47 \%$ work in accommodation and catering sectors.

Youth unemployment is a serious problem. Therefore, it is important that the tourism industry broadens horizons for youth employment. According to forecasts, by 2030 the share of Africans aged 15-25 years will reach $42 \%$ $[11 ; 16]$. Creation of new jobs for young people, taking into account their level of education and training, spread of informal internship programs in production will make young people in demand among employers in the tourism sector.

The possibilities of this region were very well reflected by the head of UNWTO Zurab Pololikashvili: "Africa has everything to position itself as a world leader in tourism. ... And African cities are real centers of innovation... With a concerted approach, we can expect the number of international tourists in Africa to reach 135 million by 2030" [8].

The main areas of tourism development on the continent include the following: nature/adventure, environmental, sightseeing (cognitive), cultural with visits to historical and cultural monuments, business, diaspora, beach, health, ethnic, safari tours, domestic and intraregional tourism.

UNWTO in Africa identifies two major tourist sub-regions: 1) North Africa (without Egypt and Libya); 2) Sub-Saharan Africa. They differ in the volume and pace of tourism development. SubSaharan Africa is ahead of North Africa in terms of tourist arrivals and revenues from tourism (Table 4). It accounts for $63.3 \%$ of the continent's tourist flow and $70.1 \%$ of its tourism income. In this subregion, tourist arrivals increased 2.8 times between 2000 and 2019, and 1.4 times between 2010 and $2019-1.4$ times with an average annual growth rate of $4.2 \%$. In North Africa, similar figures are much lower. Accordingly, they were: 2.5 times; 1.3 times and $3.0 \%$.

Table 4

International tourist arrivals among Africa's tourist subregions

\begin{tabular}{|l|l|l|l|l|l|l|l|l|l|l|}
\hline & \multicolumn{5}{|c|}{ Million } & Share, \% & \multicolumn{3}{c|}{ Change \% } & $\begin{array}{c}\text { Av. annual } \\
\text { growth, \% }\end{array}$ \\
\hline & 2000 & 2010 & 2017 & 2018 & 2019 & 2019 & $18 / 17$ & $19 / 18$ & $2010-2019$ \\
\hline Africa & 26.2 & 50.4 & 62.7 & 68.6 & 70.0 & 4.8 & 8.3 & 2.0 & 3.7 \\
\hline North Africa & 10.2 & 19.7 & 21.7 & 24.1 & 25.6 & 1.8 & 11.1 & 6.4 & 3.0 \\
\hline $\begin{array}{l}\text { Sub-Saharan } \\
\text { Africa }\end{array}$ & 16.0 & 30.7 & 41.1 & 44.5 & 44.3 & 3.0 & 6.8 & 0.4 & 4.2 \\
\hline
\end{tabular}

Developed by the author on the basis of: [22]

In 2019, total revenue from international tourism in African tourism macroregion was US $\$ 38.4$ billion, or 2.6 percent of global tourism revenue (Table 5). The regional distribution of tourism revenues is proportional to the number of tourist arrivals. In general, their growth rate in 
both subregions was less significant than the growth rate of tourist arrivals. Between 2010 and
2019, they increased by 29.3\% in Sub-Saharan Africa and by $18.5 \%$ in North Africa.

Table 5

International tourism receipts among Africa's tourist subregions

\begin{tabular}{|l|l|l|l|l|l|l|l|l|}
\hline & \multicolumn{4}{|c|}{ USD billion } & \multicolumn{2}{c|}{ Share, \% } & \multicolumn{2}{l|}{ Change $^{*} \%$} \\
\cline { 2 - 9 } & 2000 & 2010 & 2017 & 2018 & 2019 & 2019 & $18 / 17$ & $19 / 18$ \\
\hline Africa & 10.8 & 30.4 & 36.4 & 38.9 & 38.4 & 2.6 & 2.6 & 0.8 \\
\hline North Africa & $\ldots$ & 9.7 & 9.9 & 10.7 & 11.5 & 0.8 & 4.7 & 9.6 \\
\hline Sub-Saharan Africa & $\ldots$ & 20.8 & 26.5 & 28.1 & 26.9 & 1.8 & 1.8 & -2.6 \\
\hline
\end{tabular}

*real terms

Developed by the author on the basis of: [22]

In 2019, South Africa (14.797 million), Morocco (13.109 million), and Tunisia (9.429 million) had the top tourist numbers among individual countries in African tourism macroregion, accounting for $52.4 \%$ of total arrivals [7] (Fig. 1), while the top 10 accounted for $73.5 \%$. A dramatic change occurred in Tunisia, which had 7.163 million arrivals and lost about 1.8 million by 2016 due to terrorist attacks. On the continent as a whole, Egypt ranked second in terms of tourist arrivals (13.026 million).

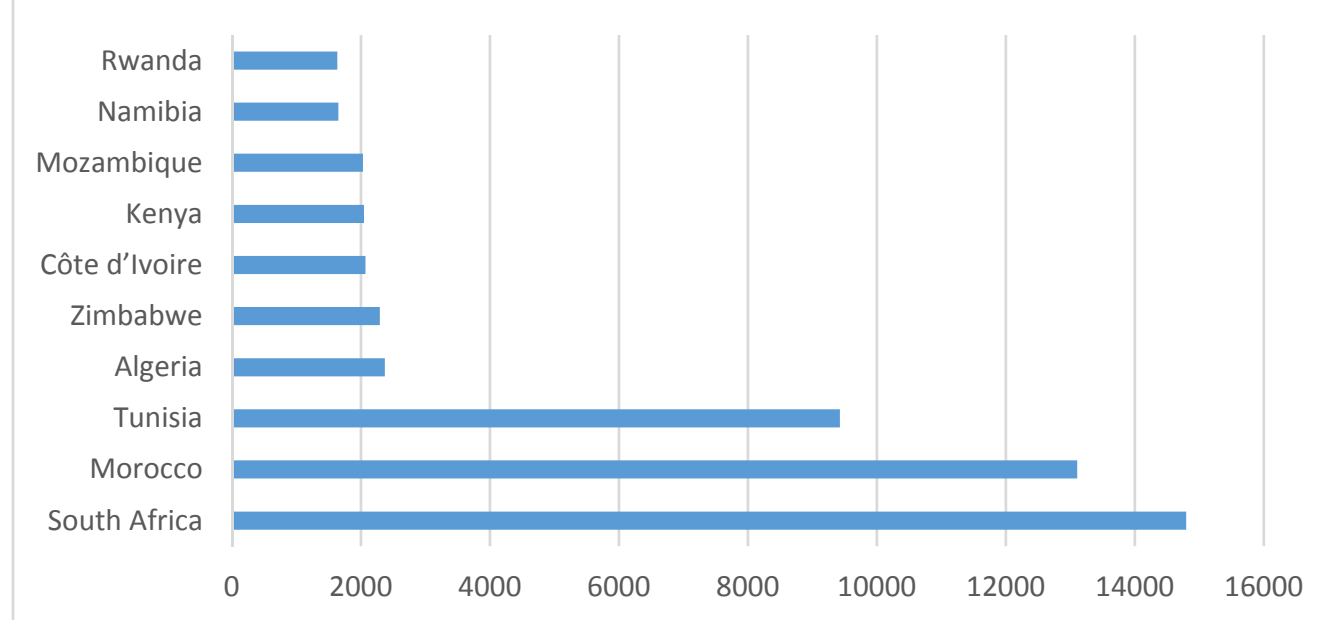

Fig. 1. The number of arrivals of international tourists in 2019, thousand Developed by the author on the basis of: [7]

Among Africa's tourism subregions, Morocco (US\$10.013 billion) and South Africa (US\$9.064 billion), received the highest international tourism revenues in 2019. These two countries accounted for $74.7 \%$ of total revenues, and the top 10 countries

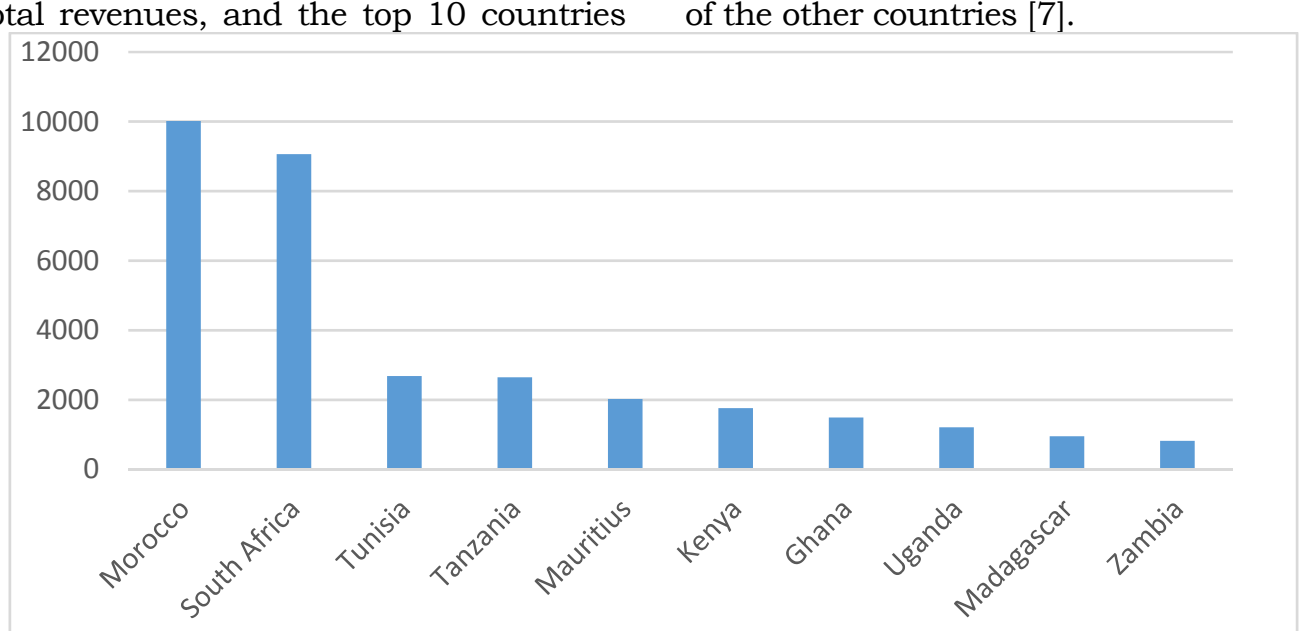

Fig. 2. Top 10 African countries in terms of international tourism revenues in 2019, USD million Developed by the author on the basis of: [7]

Calculations of paired correlation coefficients (R) indicate the presence of dependence between 220 accounted for $85.2 \%$ (Fig. 2). In third place, Tunisia (US\$2.683 billion) lags far behind. But on the continent as a whole, Egypt (US\$14.256 billion) ranked first in terms of revenues, significantly ahead of the other countries [7]. 
Paired correlation coefficients

\begin{tabular}{|c|c|c|c|c|c|c|c|c|c|c|c|}
\hline Indicator & 1 & 2 & 3 & 4 & 5 & 6 & 7 & 8 & 9 & 10 & 11 \\
\hline 1 & - & - & - & - & - & - & - & - & - & - & - \\
\hline 2 & 0.82 & - & - & - & - & - & - & - & - & - & - \\
\hline 3 & 0.65 & 0.90 & - & - & - & - & - & - & - & - & - \\
\hline 4 & 0.68 & 0.90 & 0.99 & - & - & - & - & - & - & - & - \\
\hline 5 & 0.64 & 0.89 & 0.997 & 0.98 & - & - & - & - & - & - & - \\
\hline 6 & 0.47 & 0.72 & 0.83 & 0.82 & 0.81 & - & - & - & - & - & - \\
\hline 7 & 0.88 & 0.92 & 0.92 & 0.92 & 0.91 & 0.75 & - & - & - & - & - \\
\hline 8 & 0.82 & 0.89 & 0.93 & 0.93 & 0.92 & 0.82 & 0.98 & - & - & - & - \\
\hline 9 & 0.78 & 0.65 & 0.67 & 0.63 & 0.68 & 0.55 & 0.79 & 0.78 & - & - & - \\
\hline 10 & 0.80 & 0.71 & 0.74 & 0.71 & 0.75 & 0.62 & 0.84 & 0.85 & 0.99 & - & - \\
\hline 11 & 0.86 & 0.93 & 0.89 & 0.90 & 0.89 & 0.68 & 0.98 & 0.94 & 0.77 & 0.81 & - \\
\hline
\end{tabular}

1. GDP in constant prices in 2010 , USD

2. Number of tourist arrivals, total

3. International tourism, income at current prices, USD/year

4. International tourism, income from trips and purchases, USD

5. Expenses of international tourists within the country in constant prices in 2011 , billion USD

6. Government spending at constant prices in 2011 , billion USD

7. Total contribution of tourism and travel to GDP in constant prices in 2011, billion USD

8. Direct contribution of tourism and travel to GDP at constant prices in 2011 , billion USD

9. Total contribution of tourism and travel to employment, thousand people

10. Direct contribution of tourism and travel to employment, thousand people

11. Capital investment in tourism at constant prices in 2011 , billion USD

A very strong relationship is observed between GDP and number of arrivals $(\mathrm{R}=0.82)$; total $(\mathrm{R}=0.88)$ and direct $(\mathrm{R}=0.82)$ contribution of tourism and travel to GDP; total $(\mathrm{R}=0.78)$ and direct $(R=0.82)$ contribution of tourism and travel to employment $(\mathrm{R}=0.80)$ and capital investment in tourism $(\mathrm{R}=0.86)$. A medium strength relationship is evident between GDP and international tourism revenues in general $(\mathrm{R}=0.65)$; international tourist travel and shopping revenues $(\mathrm{R}=0.68)$; international tourist domestic spending $(R=0.64)$ and government spending on tourism $(\mathrm{R}=0.47)$. Total contribution of tourism and travel to GDP is closely related to direct contribution of tourism and travel to GDP $(\mathrm{R}=0.98)$; total $(\mathrm{R}=0.79)$ and direct $(\mathrm{R}=0.84)$ contribution of tourism and travel to employment; and capital investment in tourism $(R=0.98)$.

Statistics show that in the world most international travel is done within one's own region. In Africa, four out of ten international tourists are African nationals from other countries of the continent, including two out of ten in North Africa and two out of three in Sub-Saharan Africa [16]. With the growth of the welfare of the population, size of middle class and its income, expansion and modernization of transport infrastructure, opportunities for increasing intraregional and continental tourism are increasing. Regional integration of African countries contributes to development of business tourism. For example, Ghana and Nigeria in the framework of ECOWAS (The Economic Community of West African States) attract business tourists from neighboring countries. As a result, the expenditure of such tourists in Nigeria increased by more than 300\% between 2000 and 2015 [16].

Africa attracts tourists from all over the world. Because of its proximity to Europe and Asia, tours of the northern part of the continent (including Egypt) are the most popular. In North African tourism macro-region, the position of Morocco and Tunisia is strengthening rapidly due to the increasing flow of European visitors. This trend has especially intensified after the lifting of negative travel advisories to Tunisia [21].

In recent years, Europeans are visiting southern Africa more often, as it is more colorful and interesting. Tourists are interested in the diversity of the natural environment: rainy tropics and hot deserts, unique waterfalls and canyons, beautiful mountains and caves, rich flora and fauna, parks and nature reserves, which occupy large areas. They do not remain indifferent to the numerous sites of historical and cultural heritage, buildings of ancient peoples, aboriginal settlements (Pygmies, Bushmen, Maasai, Himba) living in the wilderness, traditions, life, rituals of local people, as well as exotic cuisine. African deserts Sahara and Namib with very hot climate attract extreme tourists, where they travel on motorcycles or Jeeps [9].

In Sub-Saharan Africa, Kenya, Cote d'Ivoire, Togo, Uganda and Zimbabwe have made positive 
strides in international tourism thanks to the development of air transport and improved security. Kenya attracts many tourists with its Great Safari, and at Cape of Good Hope in South Africa you can see penguins in person. In Tanzania, Namibia, Uganda, South Africa and some other countries there are many nature reserves, national parks where you can observe a variety of animals, birds, fish and amazing insects in natural conditions. In these places hotels are open all year round for tourists.

Fishing, diving and watching rich underwater world of Indian Ocean is well organized in coastal cities of Kenya, Mozambique, Tanzania and South Africa. Tourism on the islands of Madagascar, Mauritius, Cape Verde, Réunion, Comoros and Seychelles is actively developing thanks to the expansion of air communication [21].

Development of international tourism in many African countries is used to solve both domestic and regional economic and political problems. The tasks in the field of tourism in Africa at different hierarchical levels are reflected in Table 7 , which shows importance of this industry for the economies of individual countries and the macroregion as a whole.

Table 7

Tasks in the field of tourism in Africa at different hierarchical levels

\begin{tabular}{|l|l|}
\hline \multicolumn{1}{|c|}{ Level } & \multicolumn{1}{c|}{ Tasks } \\
\hline Continental & $\begin{array}{l}\text { According to the objectives of the African Union by 2063 and its New Partnership } \\
\text { program, tourism will be an important factor for socioeconomic development and } \\
\text { structural change on the continent through creation of new jobs, recruitment of } \\
\text { women and youth in the industry, and acceleration of growth in other productive } \\
\text { sectors. Overall, tourism will contribute to reducing poverty, promoting trade } \\
\text { and fostering regional integration. }\end{array}$ \\
\hline Regional & $\begin{array}{l}\text { Tourism is important for socio-economic development, as reflected in documents } \\
\text { of some regional economic communities, namely: } \\
- \text { The 1998 Southern African Development Community Protocol on Tourism, } \\
- \text { Program of Sustainable Tourism Development of common market among } \\
\text { countries of East and Southern Africa, } \\
-2013-2023 \text { Master Plan on Sustainable Tourism Development by } \\
\text { Intergovernmental Authority. }\end{array}$ \\
\hline National & $\begin{array}{l}\text { Many African countries have national development plans for the future, which } \\
\text { define policies and sectoral priorities, indicating the important role of tourism. }\end{array}$ \\
\hline
\end{tabular}

Developed by the author on the basis of: [16]

In report "The Economic Development in Africa Report 2017: Tourism for Transformative and Inclusive Growth", prepared by the United Nations Conference on Trade and Development (UNCTAD), it is argued that tourism in Africa can complement diversified economic development and structural transformation strategies and become a promising area for inclusive growth. The report also states that in order to remove barriers and impediments to the development of the tourism sector in Africa, it is necessary to focus on the following tasks: 1) strengthen cross-sectoral linkages; 2) enhance the potential of tourism to foster more inclusive growth; 3) deepen regional integration by leveraging intra-regional tourism opportunities; and 4) promote peace and stability on the continent for tourism development [16].

Safety of travel plays an important role for tourists. On "Tourist Risk Map", which warns about the potential risks for foreign tourists abroad, in 2020 Libya and Somalia were ranked as the most dangerous places on the planet. They rank last in all three categories: personal safety, road safety and medicine. It should also be noted that the countries with the highest risk of health problems, disease and viral illnesses for foreigners include: Guinea, Niger, Liberia, Sierra Leone, Central African Republic, Eritrea and South
Sudan. Countries with extreme personal safety risks in Africa include: Somalia, Libya and parts of Nigeria. African countries stand out among other countries in the world for the greatest risk of getting into an accident [2].

During the revolutionary events in Africa, resorts in Greece, Spain, Turkey and the UAE become more popular among tourists. According to Tuespana (Spanish Institute of Tourism), in the first weeks of Tunisian revolution due to the riots about $600-650$ thousand tours were redirected to other countries. 400 thousand tourists from UK, who used to regularly spend their holidays in Egypt and Tunisia, went to Spain instead. About 250,000 Germans visited the Canary Islands instead of North African countries [20].

According to M. Katkova, the general director of Kilimanjaro LLC, Africa has "underdeveloped infrastructure and, above all, the hotel base. At the same time, the cost of the whole package with flight is high - a trip for one person costs an average of US\$5000. Those who can afford such a trip are wealthy, capricious, spoiled, they want luxury" [6].

Africa's private sector attracts investment, much of it coming from Europe and the United States. Return on investment is one of the highest in the world [26]. A significant share of investment 
in tourism sector goes to accommodation sector (hotels, resorts, lodges, etc.). Hotel industry is developed very unevenly across countries and within the country. It is mainly concentrated in the capital cities. It is better developed in North Africa (especially in Egypt, Morocco and Tunisia). Most cities in South Africa are insufficiently supplied with hotels, and many of them require renovation or even demolition.

According to BoldData, there are currently 402,933 hotels worldwide with "stars" assigned. Of these only $3.8 \%$ are in Africa. By the number of such hotels South Africa $(8,772)$, Morocco $(1,232)$, Egypt (1,087), Kenya (500) and Tanzania (419) are leading. Three hotels in Seychelles position themselves as $6^{*}$. The following countries on the continent have more than 50 five-star hotels: South Africa (643), Egypt (453), Morocco (140), Kenya (105) Sierra Leone (100) and Tanzania (59) [10].

The hotel industry could change significantly in the coming years. There are plans to build another 401 hotels with 75,155 branded rooms, including hotels in Egypt and Libya belonging to the Middle East tourist region (Table 8). New hotels will be concentrated in a small number of countries. Thus, the top 10 countries will account for $69.3 \%$ of all new hotels with $74.1 \%$ of all new rooms, while the top 20 will account for $88.8 \%$ and $91.2 \%$, respectively. The average size of the hotel varies by country, but it tends to be bigger in North and West Africa.

Table 8

Hotel Chain Development Pipelines: Top 20 countries by number of rooms, 2019

\begin{tabular}{|l|l|l|l|l|l|l|l|}
\hline Country & $\begin{array}{l}\text { Pipeline } \\
\text { Hotels }\end{array}$ & $\begin{array}{l}\text { Pipeline } \\
\text { Rooms }\end{array}$ & $\begin{array}{l}\text { Average } \\
\text { size }\end{array}$ & Country & Hotels & Rooms & $\begin{array}{l}\text { Average } \\
\text { size }\end{array}$ \\
\hline Egypt & 51 & 15,158 & 297 & Cote d'Ivoire & 13 & 2,160 & 166 \\
\hline Nigeria & 49 & 7,940 & 162 & Ghana & 9 & 1,971 & 219 \\
\hline Morocco & 36 & 6,395 & 178 & Zambia & 15 & 1,872 & 125 \\
\hline Ethiopia & 34 & 6,184 & 182 & Uganda & 11 & 1,497 & 136 \\
\hline Kenya & 27 & 4,232 & 157 & Angola & 7 & 1,163 & 166 \\
\hline Algeria & 19 & 4,147 & 218 & Niger & 5 & 1,017 & 203 \\
\hline Cape Verde & 11 & 3,479 & 316 & Libya & 3 & 826 & 275 \\
\hline Senegal & 17 & 2,829 & 166 & Mauritius & 5 & 804 & 161 \\
\hline Tunisia & 16 & 2,768 & 173 & Benin & 5 & 768 & 154 \\
\hline South Africa & 18 & 2,574 & 143 & Cameroon & 5 & 758 & 152 \\
\hline
\end{tabular}

Developed by the author on the basis of: [19]

Hotels of global hotel chains have developed mainly in major cities of Southern, Northern and Eastern Africa (on the cost of Indian Ocean and islands). Among the brands managed by chains,
Accor and Marriott International have the largest number of hotels and rooms. And the biggest increase in rooms is predicted for Mangalis Hotel Group and Rotana Hotels (Table 9).

Table 9

Top 10 Chains: Pipeline vs. Existing Hotels in Africa

\begin{tabular}{|l|l|c|c|c|c|c|}
\hline Rank & Company & \multicolumn{2}{l|}{ Pipeline } & \multicolumn{2}{l|}{$\begin{array}{l}\text { Existing } \\
\text { Pipeline vs. Existing } \\
\text { (Rooms) } \%\end{array}$} \\
\cline { 3 - 7 } & & Hotels & Rooms & Hotels & Rooms & \\
\hline 1 & Marriott International & 81 & 16,905 & 135 & 23,154 & 73.0 \\
\hline 2 & Accor & 57 & 13,543 & 162 & 27,337 & 49.5 \\
\hline 3 & Hilton & 55 & 11,209 & 44 & 12,145 & 92.3 \\
\hline 4 & Radisson Hotel Group & 47 & 8,974 & 47 & 9,583 & 93.6 \\
\hline 5 & Melia Hotels \& Resorts & 8 & 2,317 & 10 & 2,722 & 85.1 \\
\hline 6 & Rotana Hotels & 9 & 2,058 & 3 & 860 & 239.3 \\
\hline 7 & Intercontinental Hotel Group & 10 & 1,904 & 28 & 6,799 & 28.0 \\
\hline 8 & Mangalis Hotel Group & 15 & 1,781 & 3 & 425 & 419.1 \\
\hline 9 & Best Western Hotels \& Resorts & 18 & 1,613 & 22 & 1,928 & 83.7 \\
\hline 10 & Hyatt International & 8 & 1,507 & 7 & 1,518 & 99.3 \\
\hline & Total & 308 & 61,811 & 461 & 86,471 & 71.5 \\
\hline
\end{tabular}

Developed by the author on the basis of: [19]

Central African Republic, Eritrea, Gambia and Somalia have no internationally branded hotels; nor are there any hotels under development [19].

Currently, tourism development on the continent is affected by the COVID-19 pandemic, which swept the world. It has made its adjustments, when the prospects for many countries in Africa were promising. Economic growth was predicted to increase from $2.9 \%$ in 2019 to $3.2 \%$ in 2020, and to $3.5 \%$ in 2021. Major successes were observed across the continent in health care, poverty reduction, rapid pace of 
innovation, which young Africans most actively mastered [3].

COVID-19 has already negatively affected the tourism business in Africa, especially in small island countries. Since the beginning of the pandemic, many tourist attractions have been closed. In 2020, all industry's key indicators have decreased: number of jobs by 12.4 million (51\%), GDP of tourism - by 87 billion USD (51\%). International tourist arrivals decreased by $63 \%$, domestic - by $33 \%$. If the situation does not improve, the losses will be more significant (another 10-12\%) [14]. Socio-economic consequences of the pandemic may manifest themselves in the short term.

Conclusions. Tourism in Africa is a rapidly developing sector with phenomenal potential. It has all the resources to form a large, diverse regional tourism complex. The scientific and technological advances and globalization have created the conditions for the continent to unlock its full potential. However, Africa, as a very attractive and promising tourism region, is still underdeveloped. The level of tourism business development lags behind the world average and other tourist sub-regions.

The continent's integration into the world tourism market requires not only the interest of its countries in tourism development at different levels, but also putting it into practice. This is expressed in creation and improvement of appropriate infrastructure, taking measures to resolve military, political and religious conflicts, solving security problems in tourist zones, rapid response to crises of various natures, strengthening inter-sectoral and interregional relations, supporting local entrepreneurs and farmers producing products for tourists. It is also necessary to develop an effective tourism policy, taking into account the specifics of socioeconomic development and opportunities to maximize the use of tourism potential of the country. Holding multilateral negotiations will create favorable conditions for stimulating tourism activities throughout the continent. Tourism development will contribute to solving many problems of socio-economic development in Africa.

\section{АФРИКА НА СВІТОВОМУ РИНКУ ТУРИЗМУ В УМОВАХ ГАОБАМІЗАЦІї}

Юрченко Світмана Омексіївна, кандидат географічних наук, доцент, кафедра туристичного бізнесу та країнознавства, Харківський національний університет імені В.Н. Каразіна, майдан Свободи, 4, м. Харків, 61022, Україна, e-mail: s.a.jurchenko@karazin.ua; ORCID: https://orcid.org/0000-0002-3709-4317 Юрченко Охена Євгенівна, здобувач, кафедра міжнародних економічних відносин імені Артура Голікова, Харківський національний університет імені В.Н. Каразіна, майдан Свободи, 4, м. Харків, 61022, Україна, e-mail: el-tour@hotmail.com

Кондрова Анна Евгеньевна, кандидат географічних наук, доцент, кафедра економічної та соціальної географії імені академіка РАО В.П. Максаковського, Московський педагогічний державний університет, Пироговська вул. 1/1, Москва, 119991, Російська Федерація, e-mail: ae.kondrova@mpgu.su; ORCID: https://orcid.org/0000-0002-0535-678X

Туризм є перспективною галуззю країн африканського континенту, сприяє їх економічному зростанню та поліпшенню умов життя населення. Предметом цього дослідження є туристичний ринок Африки. Мета статті - показати місце Африки на світовому ринку туризму та проаналізувати тенденції туристичної діяльності в регіоні в умовах глобалізації. Дия досягнення мети вирішувались наступні завдання: показати фактори, які впливають на туристичну діяльність в Африці, проаналізувати основні параметри та тенденції розвитку міжнародного туризму в регіоні та його субрегіонах у порівнянні з світовими, виявити вплив туризму на економіку африканських країн. Використовувались наступні методи: порівняльний; історичний - для визначення тенденцій розвитку міжнародного туризму Африці; статистичний - дмя вивчення взаємозалежностей між кількісними показниками розвитку туризму в країнах Африки; аналізу та синтезу - для виявлення взаємозв'язків процесів, що протікають на туристичних ринках; системний підхід - для розкриття особливостей розвитку міжнародного туризму в умовах глобалізації. Отримані результати: виявлені періоди спаду та росту туристичної діяльності в цілому на континенті, його макрорегіонах та окремих країнах; визначені основні направлення туризму та мандрівок; виявлені основні проблеми розвитку туризму; розрахована залежність між ВВП та показниками розвитку туризму в африканських країнах; показаний вплив COVID-19 на розвиток туристичного бізнесу Африки. Висновки: в Африці активно розвивається міжнародний туризм, якій робить істотний вклад у ВВП та зайнятість населення. Однак рівень розвитку туристичної галузі залежить від низки внутрішніх на зовнішніх факторів та відстає від середньосвітового та інших туристичних субрегіонів. Необхідна розробка ефективної туристичної політики в кожній країні континенту та його субрегіонів.

КАючові слова: глобалізація, туризм, міжнародний туризм, світовий туристичний ринок, Африка, туристичні субрегіони Африки, туристичні прибуття, прибутки від туризму.

\section{АФРИКА НА МИРОВОМ РЫНКЕ ТУРИЗМА В УСАОВИЯХ ГАОБААИЗАЦИИ}

Юрченко Светмана Амексеевна, кандидат географических наук, доцент, Харьковский национальный университет имени В.Н. Каразина, пл. Свободы, 4, г. Харьков, 61022, e-mail: s.a.jurchenko@karazin.ua; ORCID: https://orcid.org/0000-0002-3709-4317 
Юрченко Елена Евгениевна, соискатель, Харьковский национальный университет имени В.Н. Каразина, пл. Свободы, 4, г. Харьков, 61022, e-mail: el-tour@hotmail.com

Кондрова Анна Евгеньевна, кандидат географических наук, доцент, Московский педагогический государственный университет, Пироговская умица 1/1, Москва, 119991, Российская Федерация, e-mail: ae.kondrova@mpgu.su; ORCID: https://orcid.org/0000-0002-0535-678X

Туризм является перспективной отраслью стран африканского континента, способствует их экономическому росту и улучшению условий жизни населения. Предметом исследования является туристический рынок Африки. Цель статьи - показать место Африки на мировом рынке туризма и проанализировать тенденции туристической деятельности в регионе в условиях глобализации. Дия достижения цели решались следующие задачи: показать факторы, влияющие на туристическую деятельность в Африке, проанализировать основные параметры и тенденции развития международного туризма в регионе и его субрегионах в сравнении с мировыми, выявить влияние туризма на экономику африканских стран. Использовались такие методы: сравнительный; исторический - для определения тенденций развития международного туризма Африки; статистический - дмя изучения взаимозависимостей между количественными показателями развития туризма в странах Африки; анализа и синтеза - для выявления взаимосвязей процессов, протекающих на туристических рынках, системный подход - дмя раскрытия особенностей развития международного туризма в условиях глобализации. Получены результаты: выявлены периоды спада и роста туристической деятельности в целом по континенту, его макрорегионам и отдельным странам; определены основные направления туризма и путешествий; выявцены основные проблемы развития туризма; рассчитана зависимость между ВВП и показателями развития туризма в африканских странах; показано влияние COVID-19 на развитие туристического бизнеса Африки. Выводы: в Африке активно развивается международный туризм, который оказывает существенный вклад в ВВП и занятость населения. Однако уровень развития туристической сферы зависит от ряда внутренних и внешних факторов и отстает от среднемирового и других туристических субрегионов. Необходима разработка эффективной туристической политики в каждой стране континента и его субрегионов.

К^ючевые слова: глобализация, туризм, международный туризм, мировой туристический рынок, Африка, туристические субрегионы Африки, туристические прибытия, доходы от туризма.

\section{Мiтература}

1. Александрова А.Ю. Типология стран мира по уровню развития международного туризма. География и природные ресурсы. 2016. № 1. С. 14-22.

2. Африка не для слабонервних. URL: https://rg.ru/2019/11/18/eksperty-nazvali-samye-opasnyestrany-dlia-turistov-v-2020-godu.html

3. Воздействие пандемии

COVID-19

Ha

https://www.un.org/sites/un2.un.org/files/africa_covid_brief_russian.pdf

4. Константинова О.В. Роль туризма в инклюзивном

https://cyberleninka.ru/article/n/rol-turizma-v-inklyuzivnom-razvitii-afriki

5. Крах туризма из-за COVID-19 может стать катастрофой для экономик стран Aфрики. URL: https://tourism.interfax.ru/ru/news/articles/69850/

6. Максимова $\Lambda . Н$. Актуальные проблемы развития индустрии гостеприимства в странах экваториальной и южной Африки. URL: https://cyberleninka.ru/article/n/aktualnye-problemy-razvitiyaindustrii-gostepriimstva-v-stranah-ekvatorialnoy-i-yuzhnoy-afriki

7. Мировой Атлас Данных. URL: https://knoema.ru/atlas

8. Новости ООН. Будущее туризма - за Африкой. URL:

https://news.un.org/ru/story/2019/09/1362642

9. Развитие туризма в Aфрике. URL: https://afrika-raj.ru/turizm-v-afrike/razvitie-turizma-vafrike.html

10. Сколько отелей в мире и где больше всего "пятизвездников". URL: https://www.atorus.ru/News/Press-Centre/New/46755.html

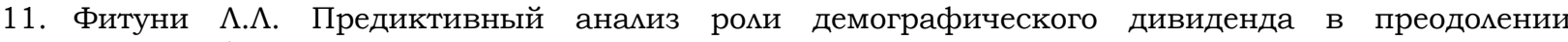
структурных дисбалансов социально-экономического развития Африки (2015-2060 гг.). Ученые записки Института Африки Российской академии наук. Выпуск № 2 (39), $2017 . \quad$ URL: http:/ / africajournal.ru/2019/01/24/предиктивный-анализ-роли-демографич /

12. Цыганов С.А., Юрченко Е.Е., Юрченко С.А. Конкурентоспособность стран мира на мировом туристическом рынке. Региональные исследования. 2015. №1 (47). С. 88-95.

13. Юрченко C.О., Юрченко О.Є. Міжнародний туризм: навчальний посібник [для студентів спеціальностей "Туризмознавство", "Міжнародні економічні відносини»]. Х. : ХНУ імені В.Н. Каразіна. 2016. 328 c.

14. Africa

Economic

Impact

from

COVID-19

URL: https://wttc.org/Portals/0/Documents/Reports/2020/Africa\%20Recovery\%20Scenarios\%20Nov\%202020.p df?ver=2021-02-25-183015-997 
15. African Union Commission, “African Youth Charter." 2006. July 2. URL: https://www.un.org/en/africa/ osaa/pdf/au/african_youth_charter_2006.pdf

16. Economic Development in Africa Report 2017: Tourism for Transformative and Inclusive Growth URL: https://unctad.org/system/files/official-document/tdb64d2_en.pdf

17. Economic Impact Reports. URL: https://wttc.org/Research/Economic-Impact

18. e-Conomy Africa 2020. URL: https://www.ifc.org/wps/wcm/connect/e358c23f-afe3-49c5-a509034257688580/e-Conomy-Africa-2020.pdf?MOD=AJPERES\&CVID=nmuGYF2
19. Egypt
heads
the Africa hotel
development
top ten.
URL:

https://africabusiness.com/2019/05/09/hotels-in-africa/

20. Instituto de Turismo de Espafia. URL: www.tourspain.es

21. International Tourism $\quad$ Highlights 2019 Edition. URL: https://tourlib.net/wto/WTO_highlights_2019.pdf
22. International
Tourism Highlights
URL:

Highlights 2020

Edition.

https://tourlib.net/wto/WTO_highlights_2020.pdf

23. Population Reference Bureau, "2018 World Population Data Sheet," 2018. August. URL: https://www.prb. org/wp-content/uploads/2018/08/2018_WPDS.pdf

24. The importance of Travel \& Tourizm in 2019. URL: https://wttc.org/Portals/0/Documents/Reports/2020/EIR\%202020\%20Importance\%20of\%20Travel\%20an d\%20Tourism\%20Infographic.pdf?ver=2021-02-25-183030-667

25. Tourism Highlights 2011 Edition. URL: https://tourlib.net/wto/WTO_highlights_2011.pdf

26. Tourism in Africa: A Tool for Development. URL: https://webunwto.s3.eu-west1.amazonaws.com/s3fs-public/2019-10/AM-Regional-Report-Volume-four-Tourism-in-Africa-A-Tool-forDevelopment.pdf

27. Tourism-WTTC-Global-Economic-Impact-Trends-2019.pdf. URL: https://ambassadeethiopie.fr/onewebmedia/Tourism-WTTC-Global-Economic-Impact-Trends-2019.pdf

28. Travel \& Tourism Global Economic Impact Trends 2020. URL: https://www.developmentaid.org/api/frontend/cms/file/2020/10/Global_Economic_Impact_Trends_2020. pdf

29. Travel \& Tourism Global Economic Impact Trends 2020. URL: https://wttc.org/Portals/0/Documents/Reports/2020/Global\%20Economic\%20Impact\%20Trends\%202020. pdf?ver=202 1-02-25-183118-360

\section{References}

1. Alexandrova, A.Y. (2016). Typology of countries around the world in terms of the development of international tourism. Geography and natural resources. 1. pp. 14-22 [in Russian].

2. Africa is not for the faint of heart URL: https://rg.ru/2019/11/18/eksperty-nazvali-samye-opasnyestrany-dlia-turistov-v-2020-godu.html [in Russian].

3. The impact of the COVID-19 pandemic on Africa. URL: https://www.un.org/sites/un2.un.org/files/africa_covid_brief_russian.pdf [in Russian].

4. Konstantinova O.V. The role of tourism in the inclusive development of Africa. URL: https:/ / cyberleninka.ru/article/n/rol-turizma-v-inklyuzivnom-razvitii-afriki [in Russian].

5. Крах туризма из-за COVID-19 может стать катастрофой дмя экономик стран Aфрики URL: https://tourism.interfax.ru/ru/news/articles/69850/ [in Russian].

6. Maximova L. N. Actual problems of the development of the hospitality industry in the countries of Equatorial and Southern Africa. URL: https://cyberleninka.ru/article/n/aktualnye-problemy-razvitiyaindustrii-gostepriimstva-v-stranah-ekvatorialnoy-i-yuzhnoy-afriki [in Russian].

7. World Data Atlas. URL: https://knoema.ru/atlas [in Russian].

8. UN News. The future of tourism is in Africa. URL: https://news.un.org/ru/story/2019/09/1362642 [in Russian].

9. Tourism development in Africa URL: https://afrika-raj.ru/turizm-v-afrike/razvitie-turizma-vafrike.html [in Russian].

10. How many hotels in the world and where are the most "five-star" hotels? URL: https://www.atorus.ru/News/Press-Centre/New/46755.html [in Russian].

11. Fituni, L.L. (2017). Predictive analysis of the role of the demographic dividend in overcoming structural imbalances in the socio-economic development of Africa (2015-2060). Scientific notes of the Institute of Africa of the Russian Academy of Sciences. № 2 (39). URL: http://africajournal.ru/2019/01/24/предиктивныйанализ-роли-демографич/ [in Russian].

12. Tsyganov, S.A., Iurchenko, E.E., Iurchenko, S.A. (2015). Competitiveness of the countries of the world in the world tourism market. Regional studies. 1 (47). pp. 88-95. [in Russian].

13. Iurchenko, S.O., Iurchenko, O.E. (2016). International tourism: a textbook. Kharkiv. V. N. Karazin Kharkiv National University. 328 p. [in Ukrainian].

14. Africa from Impact Economic COVID-19 URL: https://wttc.org/Portals/0/Documents/Reports/2020/Africa\%20Recovery\%20Scenarios\%20Nov\%202020.p df?ver=2021-02-25-183015-997 
15. African Union Commission, "African Youth Charter," July 2, 2006. URL: https://www.un.org/en/africa/ osaa/pdf/au/african_youth_charter_2006.pdf

16. Economic Development in Africa Report 2017: Tourism for Transformative and Inclusive Growth URL: https://unctad.org/system/files/official-document/tdb64d2_en.pdf

17. Economic Impact Reports. URL: https://wttc.org/Research/Economic-Impact

18. e-Conomy Africa 2020 URL: https://www.ifc.org/wps/wcm/connect/e358c23f-afe3-49c5-a509034257688580/e-Conomy-Africa-2020.pdf?MOD=AJPERES\&CVID=nmuGYF2
19. Egypt heads the Africa hotel
development
top ten.
URL:

https://africabusiness.com/2019/05/09/hotels-in-africa/

20. Instituto de Turismo de Espafia. URL: www.tourspain.es

21. International Tourism Highlights 2019 Edition. https://tourlib.net/wto/WTO_highlights_2019.pdf

22. International Highlights 2020 Edition. URL:

https://tourlib.net/wto/WTO_highlights_2020.pdf

23. Population Reference Bureau, "2018 World Population Data Sheet," August 2018. URL: https: / /www.prb. org/wp-content/uploads/2018/08/2018_WPDS.pdf

24. The importance of Travel \& Tourizm in 2019. URL: https://wttc.org/Portals/0/Documents/Reports /2020/EIR\%202020\%20Importance\%20of\%20Travel\%20an d\%20Tourism\%20Infographic.pdf?ver=2021-02-25-183030-667

25. Tourism Highlights 2011 Edition URL: https://tourlib.net/wto/WTO_highlights_2011.pdf

26. Tourism in Africa: A Tool for Development. URL: https://webunwto.s3.eu-west1.amazonaws.com/s3fs-public/2019-10/AM-Regional-Report-Volume-four-Tourism-in-Africa-A-Tool-for-

Development.pdf

27. Tourism-WTTC-Global-Economic-Impact-Trends-2019.pdf. URL: https://ambassadeethiopie.fr/onewebmedia/Tourism-WTTC-Global-Economic-Impact-Trends-2019.pdf

28. Travel \& Tourism Global Economic Impact Trends 2020. URL: https://www.developmentaid.org/api/frontend/cms/file/2020/10/Global_Economic_Impact_Trends_2020. pdf

29. Travel \& Tourism Global Economic Impact Trends 2020. URL: https://wttc.org/Portals/0/Documents/Reports/2020/Global\%20Economic\%20Impact\%20Trends\%202020. pdf?ver=2021-02-25-183118-360

Статтю отримано 27 квітня 2021 р. 